\title{
ISLAM NORMATIF DAN HISTORIS (FAKTUAL): Ziarah Epistemologi Integratif-Interkonektif dalam Pendidikan
}

\author{
NORMATIVE AND HISTORICAL ISLAM (FACTUAL): \\ A Pilgrimage the Integrative-Interconnected Epistemology in Education
}

\author{
Amril M. \\ Universitas Islam Negeri Sultan Syarif Kasim Riau, Indonesia \\ Email: amrilm@uin-suska.ac.id
}

\begin{abstract}
Abstrak
Tulisan ini memfokuskan pada diskusi tentang Islam normatif dan historis (faktual) dalam konteks ziarah epistemologis integratifinterkonektif dalam pendidikan. Penelitian ini menggunakan metode analitik deskriptif, yang mengeksplorasi konsep yang ditawarkan oleh para ilmuwan, terutama oleh M. Amin Abdullah. Studi ini menemukan bahwa menerapkan epistemologi yang saling berhubungan secara integratif dengan menjalin tiga penerus: Hadharat an-Nash (Budaya Teks dan Turats), Hadharat al-'Ilm (Budaya Budaya) dan Hadharat alFalasafah (Budaya Filsafat-Etis), yang diyakini dapat menetralkan atau setidaknya menghancurkan es antara Islam normatif dan Islam historis, dan juga pencapaian kebenaran yang akan dihasilkan tentu akan jauh lebih dekat dengan kebenaran yang lebih komprehensif daripada jika dilakukan hanya dengan satu kategori epistemologis. Pendidikan Islam, baik sebagai institusi dan sebagai subjek atau subjek, termasuk penelitian dan pengembangan ilmu-ilmu Islam, terutama yang memiliki paradigma epistemologis, integratif-interkoneksi, menjadi instrumen strategis untuk mengekspresikan cita-cita cita-cita moral dalam Islam, kemudian mencapainya sehingga perdamaian yang direkonsiliasi menyarankan bahwa selain dominasi dan penindasan sebagai bentuk nyata karakter Islam rahmatan li al-'alamin dalam realitas sosial kehidupan semakin fungsional.
\end{abstract}

Kata Kunci: Islam historis, epistemologi integratif-interkonektif, pendidikan Islam, Islam normatif.

\begin{abstract}
This paper focuses on the discussion of normative and historical (factual) Islam in the context of the integrative-interconnected epistemological pilgrimage in education. This study uses descriptive analytic methods, which explore the concepts offered by scientists, especially by M. Amin Abdullah. This study found that applying integrative-interconnected epistemology by intertwining the three successors: Hadharat an-Nash (Text Culture and Turats), Hadharat al-'Ilm (Science Culture) and Hadharat al-Falasafah (Philosophical-Ethical Culture), which believed to be able to neutralize or at least break the ice between normative Islam and historical Islam, and also the achievements of truth that would be
\end{abstract}


produced would certainly be much closer to a more comprehensive truth than if it were done with just one epistemological category. Islamic education, both as an institution and as a subject or subject, including research and development of Islamic sciences, especially those with an epistemological paradigm, integrative-interconnected, become strategic instruments for expressing the ideals of moral ideals in Islam, then achieving them so that peace is reconciled advise that apart from domination and repressiveness as a tangible form of Islamic character rahmatan li al-'alamin in the social reality of life is increasingly functional.

Keywords: historical Islam, integrative-interconnected epistemological, Islamic education, normative Islam.

\section{A. Pendahuluan}

Islam sebagai objek kajian ilmu yang dalam hal ini disebut dengan Islamic Studies sesungguhnya telah memberikan kontribusi yang teramat besar terhadap pemahaman masyarakat terhadap Islam itu sendiri, khususnya para cendikiawan dan ilmuwan. Melalui kajian Islamic Studies ini kelompok ilmuwan dan cendikiawan saat ini semakin menyadari bahwa Islam tidak lagi dilihat sebagai dogma yang final, rigid dan kaku tetapi sesungguhnya Islam telah membuka dirinya untuk ditelaah dari berbagai disiplin ilmu pengetahuan. Sedemikian rupa studi Islam dan nama lain yang seirama dengan itu telah menjadi branding ilmiah yang mendapat sambutan luar biasa di berbagai perguruan tinggi di berbagai belahan dunia saat ini termasuk di Indonesia.

Terminologi Islam normatif dan historis atau faktual sesungguhnya telah menjadi hard core dalam kajian studi keIslaman, bahkan pijakan dasar dalam kajian ini sesunguhnya berada pada lingkup Islam normatif dan historis ini yang terus didiskusikan dan didialogkan oleh para pengkaji dan ilmuwan yang memiliki kepedualian akan pencarian Islam yang sesungguhnya dalam berkehidupan dan sekaligus juga menguak proses epistemologi wajah Islam yang tampil di hadapan kita saat ini. Pada bagian yang terakhir ini lah dimaksudkan ziarah epistemologi dalam tulisan ini. Tegasnya sisi epistemologi pada tulisan ini terlacak dari tampilan upaya tulisan ini yang menjajaki model pemikiran yang tampil pada dua kategori Islam ini, yaitu normatif dan historis. Penjajakan pencarian ini lebih difokuskan pada cara pencarian kebenaran pada dua kategori Islam ini, kemudian juga implementasinya dalam pendidikan dan pembelajaran 


\section{B. Islam Normatif dan Historis: Melacak Jejak Epistemologi}

Secara kategoris, Islam normatif dan Islam historis selalu dipertentangkan, hal ini bukan saja lantaran dua kata ini dalam kaedah bahasa berwatak antonim tetapi lebih dari itu sejatinya memang dikarenakan memiliki cara pandang yang berbeda satu dengan lainnya, dimulai dari sudut world view sebagai ranah kajian ontologinya maupun dari sudut model metodis berpikir sebagai ranah kajian epistemologinya untuk mendekati sebuah kebenaran. Karenanya dalam konteks seperti ini sangat mudah dipahami adanya pendapat umum yang mengatakan bahwa dua kategori ini seakan tak akan pernah dapat didialogkan apalagi saling membutuhkan.

Kondisi seperti ini semakin diperparah lagi ketika telah terpenjara dan terkooptasi oleh kepentingan kelompok dan telah pula ditarik masuk dalam ranah kosumsi politik (political consumption), maka yang akan terjadi di antaranya mudahnya lahir gesekan dan ketegangan sosial dalam realitas kehidupan masyarakat umat beragama, dan lebih mengerikan lagi sebagaimana diungkap oleh Jacques Derrida adalah munculnya upaya dogmatisasi dengan segala bentuk perangkat institusi rasionalisasi bertujuannya dengan dukungan kekuatan rasio an sich yang didasarkan pada grand teori yang telah dimapankan yang menjelma dengan wajah logosentrisme oposisi biner. $^{1}$

Namun di balik ketegangan antara Islam normatif dan Islam historis yang telah terlanjur dalam realitas kehidupan sosial sebagaimana dirasakan saat ini, baik tertutup maupun terbuka, pertanyaan yang mendesak untuk dicari tahu jawaban solusinya adalah masih adakah ruang dialog komunikatif emansipatoris bagi dua kategori Islam ini melalui ranah epitemologi sehingga hasil temuan dapat diterima oleh dua belah pihak? Bila jawabannya "ya" lantas bagaimana terapan metodisnya?

Berharap melalui ranah epistemologi bukanlah sesuatu yang dipaksakan, karena selain kajian dalam ranah ini memang ditujukan dan mengedepankan proses pencarian bebenaran dengan validitas instrumen pencari kebenaran yang diyakini serta menformulasikan tipe-tipe kebenaran dengan kekuatan dan kelemahannya, maka yang lebih meniscayakan lagi terbukanya dialog ini lebih dikarenakan bahwa bukankah world

${ }^{1}$ Heri Susanto, "Metode Dekonstruksi Jacques Derrida: Kritik atas Metapisika dan Epistemologi Moder," dalam Listiyono Santoso, et.al., Epistemologi Kiri (Yogyakarta: Ar-Ruzz, 2009), 251 
Amril M.: Islam Normatif dan Historis (Faktual): Ziarah Epistemologi Integratif-Interkonektif dalam Pendidikan

view itu terbentuk oleh epistemological beliefs dan metaphysical beliefs. ${ }^{2}$ Meskipun menurut Thomas F. Wall metaphysical beliefs justru lebih berpengaruh. ${ }^{3}$

Pernyataan Thomas F. Wall di atas tidak selamanya valid setidaknya dilihat dari kenyataan empiris kajian yang diusahakan oleh filosuf postmodern saat ini, misalnya Michel Foucault dengan kritik logosentrismenya; bahwa suatu kekeliruan yang fatal ketika menempatkan teks, narasi itu di atas segala-galanya sehingga kebenaran yang dibangun adalah kebenaran di dalam narasi, bukan di dalam fenomena sosial yang tengah berlansung, atau Paul Karl Feyerabend dengan Against Method, pengagungan hanya pada satu metode yang dinilai valid untuk pencarian sebuah kebenaran pada hal sesungguhnya pencaian seperti ini membawa petaka, karena kebenaran yang dicapai itu tergradasi pada kebenaran metodis. Karl R. Popper dengan falsifikasinya, sebuah kebenaran dari teori atau konsep tertentu ditentukan kebenarannya ketika lulus uji dari teori atau ide lain yang menentangnya, sehingga sebuah narasi yang selama ini selalu diapresiasi sebagai sesuatu grand teory yang maha benar akan gugur dan tidak dapat dijadikan rujukan pencari kebenaran. Hasan Hanafi dengan al-Yasar al-Islami (kiri Islam) yang mendobrak kemampanan kebenaran kelompok dan penguasa melalui hegemoni tafsir agama, sehingga menjadikan penguasa sebagai pemegang otoritas kebenaran, akibatnya kebenaran tergradasi pada tangan-tangan kekuasaan. Dan masih banyak filosof post moderen lainnya yang pada intinya diawali dengan mengkritik keangkuhan epistemologi modern terutama positivisme yang melahirkan dogmatisasi world view pada hampir semua ranah keilmuan yang berakhir pada ideologisasi kebenaran yang menghegemoni.

Di balik kritik epistemologi para filosof postmodernisme di atas setidaknya ada satu pesan kuat yang disampaikan mereka bahwa kebenaran yang didapat melalui satu model epistemologi saja, atau menafikan yang lain, atau menutup rapat dari pemikiran kritis lain dan bertumpu pada grand teory atau narasi tanpa mengindahkan sisi meta teori, narasi, menurut mereka temuan kebenaran seperti itu adalah kebenaran yang rapuh dan tidak menunjukkan kualitas keberan yang sesungguhnya.

\footnotetext{
${ }^{2}$ Amril M, Epistemologi Integratif-Interkonektif Agama dan Sains (Menggali Potensi-Konsepsi Menuju Teori-Aplikasi dalam Pengembangan Ilmu Keislaman dan Pembelajaran) (Jakarta: Rajawali Press, 2016), 81

${ }^{3}$ Thomas F. Wall, Thinking Critically About Philosophical Problems (London: Wadworth, 2001), 126
} 
Dalam hal ini dapat dikatakan bahwa persoalan keyakinan pada world view berawal dari kajian epistemologi dan juga justru kajian epistemologi ini pula dapat menggeser keyakinan pada world view. Dalam konteks pemahaman seperti inilah ditegaskan apa yang dikatakan oleh Thomas F. Wall masih terbuka untuk dikritisi dan diperbaharui.

Pertanyaan yang mendasar sebagai tututan utama dalam tulisan ini adalah jika dua kategori perilaku keagamaan ini dari sudut epistemologi niscaya didialogkan lantas terapan dan implikasinya akankah dapat mengurangi atau mengelaminasi praksis keberagamaan yang telah terdikotomi.

Sebelum menjawab dari pertanyaan solusif di atas, maka terlebih dahulu ditelaah model-model berpikir yang kemungkinan menyeruak pada masing-masing Islam ini. Kata "kemungkinan" dipakai di sini untuk mengakomodir perkiraan implikasi dan konsekuensi yang lahir dari makna etimologi dua kata yang mengiringi Islam dalam tulisan ini.

Normatif yang berasal dari kata norm berarti berpegang teguh pada norma atau pada kaedah yang telah ditetapkan. Sedangkan historis yang berasal dari kata history berarti segala sesuatu yang berhubungan dengan sejarah atau kesejarahan. Dengan demikian Islam normatif adalah Islam yang berpegang teguh dengan norma dan prinsip yang telah ditetapkan, sedangkan Islam historis adalah Islam yang berpegang pada gejala dan fenomena yang berhubungan realitas kesejarahan kehidupan manusia yang dinamis.

Perbedaan watak kedua kata ini sesungguhnya melahirkan cara pandang yang berbeda pula secara organik pada pemahaman kajian Islam, baik pada ranah ontologis maupun ranah epistemologis, selanjutnya melahirkan kesimpulan yang berbeda satu dengan yang lainnya. Kondisi seperti ini akan memunculkan pula realitas kehidupan sosial keberagamaan ke arah truth claim yang offensif terhadap paham yang berseberangan dengan paham kelompok mereka. Dari sinilah ketegangan dan kecurigaan tersulut kemudian kegaduhan dan kekacauan menyeruak dalam kehidupan.

Islam sebagaimana agama-agama yang lain memiliki beragam dimensi. Ninian Smart misalnya, seorang fenomenolog dan filosuf agama mengatakan bahwa agama itu memiliki tujuh dimensi; dimensi mistis, ritual, sosial, etis, doktrinal, pengalaman, dan 
Amril M.: Islam Normatif dan Historis (Faktual): Ziarah Epistemologi Integratif-Interkonektif dalam Pendidikan

materiil. ${ }^{4}$ Aksentuasi yang berbeda ketika pencarian pemahaman ideal dari pesan-pesan moral teks oleh penganutnya menjadikan Islam memiliki prediket yang beragam pula. Islam normatif dan Islam historis misalnya tidak dapat dipisahkan dari cara padang pencarian terhadap Islam yang berbeda-beda yang kemudian dipetakan oleh pengkaji dalam kajian studi Islam. Dengan demikian, sesungguhnya terminologi Islam normatif dan Islam historis merupakan hasil olah pikir para ahli studi agama khususnya setelah mencermati dan meneliti perilaku pencarian epistemologi kebenaran keagamaan dan tampilan keberagamaan dalam realitas sosial. Beriringan dengan semuanya ini tidak dapat pula dipisahkan melahirkan pula pemahaman ontologis metafisik yang berbeda dalam keyakinan masing-masing penganutnya. Karena keterbatasan yang tidak dapat dihindari maka untuk yang terakhir ini tidak dibahas pada tulisan ini.

Tidak dapat dipungkiri bahwa munculnya terminologi Islam normatif, Islam historis, Islam liberal, Islam faktual dan seterusnya sesungguhnya berada dalam kawasan kajian studi pemikiran agama. Karena Islam sebagai ajaran dan perilaku individual atau pun sosial memungkinkan untuk dikaji dengan berbagai pendekatan disiplin ilmu-ilmu di luar kajian keilmuan agama ( 'ulum al-din).

Lahirnya istilah Islam normatif dan Islam historis tidak dapat dilepaskan begitu saja dari begitu intensnya kajian terhadap Islam sebagai ilmu yang telah sangat marak di lingkunan kampus sejak tahun 1960-an. Fazlur Rahman seorang intelektual Muslim yang berkiprah dalam bidang akademik di dunia Barat telah menampilkan model kajian terhadap Islam sebagai objek kajian ilmu. Bukunya yang sangat terkenal berjudul Islam (1966) dapat disebut sebagai penanda telah dimulainya pergeseran paradigma epistemologi-metodologi dalam kajian keIslaman dari yang bersifat normatif-teologis semata bergerak pada historis-teologis. Simpulan yang dapat diambil dalam catatan kecil ini dari apa yang ditampilkan Fazrul Rahman melalui bukunya Islam ini adalah bahwa beliau telah memulai memanfaatkan pendekatan historis dalam membentuk terciptanya dogma dan hasil pemikiran dari berbagai ranah kehidupan intektual Islam dalam bidang ilmu yang dihasilkan pada masa itu.

Setidaknya karakter pemikiran Fazlur Rahman seperti ini diungkap oleh Syafii Ma'arif dalam pengantarnya untuk buku Islam (1984) ini versi Indonesia. Bagi Fazlur Rahman bawha prosedur yang benar untuk memahami al-Qur'an mesti diakukan dalam

${ }^{4}$ Ninian Smart, "Pengantar Aneka Pendekatan Studi Agama," dalam Peter Connolly, Aneka Pendekatan Studi Agama, Terj. Imam Khoiri (Yogyakarta: LkiS, 2002), 9 
dua hal. Pertama; seseorang harus mempelajari al-Qur'an dalam ordo historisnya untuk mengapreasiasi tema-tema dan gagasan-gagasannya. Bila tidak demikian seseorang boleh jadi akan tersesat dalam memahami beberapa butir penting tertentu dari ajarannya. Kedua; seseorang harus mengkajinya dalam konteks latarbelakang sosiohistorisnya. Hal ini tidak saja berlaku untuk ayat-ayat al-Qur'an secara individual, tetapi juga untuk al-Qur'an secara keseluruhan. Tanpa memahami latar belakang mikro dan makronya secara memadai menurut Rahman, besar kemungkinan seseorang akan tersalah menangkap terhadap elan dan maksud al-Qur'an serta aktivitas Nabi baik di Makkah maupun di Madinah. ${ }^{5}$

Bila buku Islam (1966) terbitan pertama dalam bahasa Inggris ini disebut sebagai pendobrak epistemologi-metodologi kajian terhadap Islam sebagai ilmu dengan memanfaatkan pendekatan sejarah, maka buku keduanya dengan judul Islam and Modernity: Transformation of an Intellectual Traditions (1982), menurut M. Amin Abdullah, menampilkan sikap lebih kritis yang ditujukan pada model pengkajian Islam sebagai ilmu yang dilakukan oleh sarjawan dan intelektual Muslim yang berlangsung selama ini. Menurut Rahman bahwa kajian ilmu-ilmu keislaman sangat repetitif, selalu mengulang-ulang, sarat dengan literatur-literatur yang hanya berupa komentar, penjelasan dari suatu karya... dan sangat sedikit membuahkan pikiran-pikiran maupun gagasan baru. Pergumulan intelektual Islam menurut pandangannya, selama ini tidak diarahkan untuk pencapaian-pencapaian gagasan baru, melainkan hanya dimanfaatkan untuk mempertahankan pengetahuan yang telah ada. Semestinya yang dilakukan adalah memanfaatkan apa yang disebutnya dengan metode perdebatan, yang memungkinkan munculnya (temuan baru) dan menangkap isu-isu aktual lainya. ${ }^{6}$

Guna mempertahankan keyakinannya akan Islam sebagai agama satu sisi dan sebagai ilmu pada sisi lain, maka di sini Rahman menggunakan istilah normatif dan historis. Dua kata ini dia pakai untuk menvalidasi kritik-kritiknya dalam memaparkan perbedaan yang tajam pada aspek Islam antara normatif dan historis. Dalam konteks seperti inilah pemahaman akan sebutan Islam normatif dan Islam historis diletakkan dan terus mengelinding dalam setiap kajian keIslaman. Tegasnya, pemaknaan Islam dalam dua kategori ini untuk tulisan ini lebih dipahami sebagai usaha epistemologi bagi

\footnotetext{
${ }^{5}$ Fazlur Rahman, Islam, Terj. Ahsin Muhammad (Bandung: Pustaka, 1984), viii

${ }^{6} \mathrm{M}$. Amin Abdullah, Islamic Studies di Perguruan Tinggi Pendekatan Integratif-Interkonektif (Yogyakarta: Pustaka Pelajar, 2006), 27
} 
Amril M.: Islam Normatif dan Historis (Faktual): Ziarah Epistemologi Integratif-Interkonektif dalam Pendidikan

pencari kebenaran pesan-pesan ideal Islam, meskipun tidak terelakan implikasi praktis dalam realitas sosial kehidupan beragama di tengah-tengah masyarakat.

Khusus di Indonesia, M. Amin Abdullah, seorang intelektual Muslim dari UIN Sunan Kalijaga Yogyakarta dengan karyanya seperti Falsafah Kalam (2009), Studi Agama: Normativitas dan Historisitas (1996), Islamic Studies di Perguruan Tinggi Pendekatan Integratif-Interkonektif (2006), dikategorikan sebagai akademisi yang paling menonjol dan intens di antara akademisi lainnya seperti Nurcholis Majid, Azzumardi Asra, Atho’ Mudzhar dan seterusnya dalam menyebarluaskan studi agama di lingkungan masyarakat akademis yang memperluas kajian keIslaman dengan pendekatan disiplin ilmu di luar 'ulum al-din.

Mencermati arti yang tercakup pada kata normatif dan historis dipaparkan di muka dalam tatapan epistemologi yang kemudian dilekatkan pada Islam, maka mempertegas pada suatu pemahaman bahwa Islam normatif mendasari kebenaran pesan-pesan moral Ilahiyah pada ketentuan-ketentuan yang telah baku, disepakati dan menjadi prinsip yang mesti diikuti. Temuan kebenaran yang diidamkan lebih tertuju pada kebenaran eiditis-substantif bukan segala sesuatu di luar itu, sehingga sulit membuka ruang adanya kemungkinan kebenaran lain semisal kebenaran fenomenologis-fungsional. Jika pun dilakukan penafsiran maka perilaku epistemologi ini cenderung pada pola teoritical hermeneutic dan tafsir bil ma'tsur.

Model pencarian kebenaran seperti ini misalnya berangkat dari asumsi apriori yang menyakini bahwa sebuah kebenaran itu telah ditakdirkan begitu adanya sedemikian rupa berada pada wilayah prinsip yang cenderung dogmatis. Klaim kebenaran yang sesunguhnya hanya pada wilayah eiditis-substantif yang dalam perspektif kajian ontologi filsafat ilmu berada pada wilayah idealisme yang menempatkan noumena sebagai sumber lahirnya fenomena, atau alam realitas merupakan bayangan dari alam idea. Dan pada alam noumena dan idea ini lah eiditissubstantif itu berada dan menjadi bidikan utama bagi kajian Islam normatif.

Sedemikian rupa pencarian epistemologi menjadikan rasio ditempatkan sebagai pemain utama. Instrumen pencarian epistemologi lain ditundukkan kepada rasio bahkan dalam bentuk ekstrem cenderung dinafikan. Dalam konteks pemikiran filosuf Muslim era klasik di antaranya menempatkan rasio bagian dari intuisi seperti dalam pemikiran 
al-Ghazali mewakili kaum sufis moderat, atau mensejajarkan keduanya seperti pada pemikiran Raghib al-Isfahani mewakili kaum hukama moderat. ${ }^{7}$

Model berpikir deduktif ini tentunya tidak dapat dihindari dalam Islam normatif. Penguraian-penguraian dari prinsip menjadi bagian-bagian baik dalam bentuk implikasi maupun implementasi menjadi pekerjaan epistemologi pada Islam kategori ini. Menafsirkan konsep atau prinsip yang telah ada akan membawa pula pada model kerja tafsir bil-ma'tsur atau theoritical hermeniutic yang cenderung melahirkan makna yang terbatas, bahkan pada titik tertentu hanya melahirkan reproduksi makna.

Hal seperti ini membawa apa yang disebut dengan kebenaran coherensive sebagai validasi untuk menetapkan sebuah kebenaran. Maksudnya bahwa kebenaran dari sebuah stement, ide, teori atau konsep ditentukan oleh dukungan statement, ide, konsep yang lain. ${ }^{8}$ Konsekuensi kajian-kajiannya akan mudah terjebak dalam kajian yang repetitif dan reproduktif terhadap Islam yang tidak bisa dihindari sebagaimana yang ditengarai oleh Fazrul Rahman seperti disampaikan di atas.

Model epistemologi seperti ini dalam perjalanan aktivitas akademis keilmuan Islam, sesungguhnya telah cukup berlangsung lama bahkan kehadirannya bersamaan lahirnya peradaban Islam di era klasik paroh kedua. Al-Jabiri misalnya dengan terminologi nalar bayani, untuk hal-hal tertentu, dapat dikatakan salah satu bentuk referesentasi model berpikir dalam Islam normatif ini. Dikatakan demikian mengingat model berpikir bayani ini ditandai dengan upaya yang menempatkan dominasi teks dalam setiap kajian dibandingkan instrumen pencari kebenaran lainnya yakni akal/pengalaman dan intuisi/qalb. ${ }^{9}$

Menjelaskan dari prinsip atau konsep baku yang telah ditakdirkan demikian adanya selain sebagai pagar hidup untuk sulit dilompati, juga memagar rapat pada pencarian konsep mikiran tertuju pada kebenaran eiditis-substantif sebagai bagian yang hakiki yang mendasari dari sebuah kebenaran utama dari sebuah kebenaran Kebenaran tekstual menjadi upaya epistemologi yang terus dilakukan dalam pencarian kebenaran. Watak pencarian pada yang hakiki dan inheren melalui penafsiran tekstual

\footnotetext{
${ }^{7}$ Amril M., Etika Islam: Telaah Pemikiran Filsafat Moral Raghib al-Isfahani (Yogyakarta: Pustaka Pelajar, 2002), 212

${ }^{8}$ Leorens Bagus, Kamus Filsafat (Jakarta: Gramedia, 1996), 470-471

${ }^{9}$ M. Amin Abdullah, Islamic Studies..., 202-203
} 
Amril M.: Islam Normatif dan Historis (Faktual): Ziarah Epistemologi Integratif-Interkonektif dalam Pendidikan

yang tertuju pada penggalian eiditis-substantif dijadikan alasan utama untuk mengklaim sebuah kebenaran.

Berbeda dengan pencarian kebenaran epistemologi Islam historis, yang menempatkan world view-nya terhadap sesuatu pada real, dan fact yang sangat berseberangan dengan Islam normatif yang menempatkan world view-nya pada idea dan ought to membawa konsekuensi pada kinerja epistemolgi dalam pencarian kebenaran seperti telah dielaborasi di atas.

Mengingat makna etimologis dari kata historis mencakup kesejarahan dan kenyataan yang dihadapi sebagai yang real, atau keadaan yang sedang berlangsung dalam kehidupan nyata, maka substansi being adalah pada dunia empris, nyata, terdeteksi yang hidup berdinamika dalam keberlangsungan pengalaman yang dihadapi oleh umat manusia dan lingkungannya.

Berbeda dengan Islam historis yang mendasari kebenaran pesan-pesan moral pada fenomena dan dinamika alam dan sosial sebagai keyakinan ontologis bagi kelompok ini, maka dalam kajian filsafat ilmu ranah epistemologinya disebut dengan empirisme. Istilah historis dalam konteks kajian filsafat ilmu sesungguhnya tidak dapat dipisahkan dari empirisme ini. Pencarian kebenaran pada emperisme ini lebih ditumpukan pada persepsi, indra atau pengalaman sebagai instrumen yang valid untuk mendapatkan sebuah kebenaran.

Dalam konteks makna Islam historis tentunya menempatkan fenomena sosial, personal dan ekologial bahkan kultural menjadi fokus dan awal berangkat untuk pencarian kebenaran. Sehingga kepekaan terhadap dinamika sosial dan lingkungan menjadi konsen bagi aliran epistemologi seperti ini.

Implikasi lain dari pencarian epietemologis seperti ini akan menempatkan sebuah kebenaran bagian yang tidak terpisahkan dari kungkungan ruang dan waktu. Dalam konteks seperti inilah mudah dipahami kenapa kehidupan keberagmaan bagi Islam historis tidak dogmatis dan tidak pula ideologis.

Pertanyaan yang tidak bisa dihindari di antaranya adalah pada wilayah keberagamaan yang mana kajian Islam historis itu ditempatkan. Untuk menjawab ini pendapat seorang filusuf Muslim klasik bernama Raghib al-Isfahani perlu dipertimbangkan. Baginya Islam memiliki dua bidang yakni bidang ahkam syari'ah dan bidang makarim syari'ah. Baginya dimaksud dengan ahkam syari'ah adalah ketetapan 
yang sudah pasti begitu adanya baik pada prinsip maupun pada ajaran-ajaran agama. Bila ditinggalkan pelakunya diberikan predikat dengan zhalim dan bila dilaksanakan diberikan predikat dengan 'adil. Sedangkan makarim syari'ah adalah ajaran-ajaran agama Islam dalam usaha menempurnakan atau mengelokkan apa yang telah ditetapkan pada ahkam syari'ah. ${ }^{10}$ Perlu juga dijelaskan bahwa bagi Raghib al-Isfahani posisi ahkam syariah itu sebagai dasar atau pondasi bagi makarim syariah, bahkan dalam bahasa agama dikatakannya bahwa ahkam syariah itu pada posisi yang wajib sedangkan makarim syariah itu pada posisi yang sunat. ${ }^{11}$

Guna memahami Islam historis dalam takaran konsep Raghib al-Isfahani seperti diungkapkan di atas menunjukkan bahwa temuan kebenaran yang diraih oleh Islam historis adalah dalam rangka usaha menyempurnakan dan mengelokkan Islam normatif. Tidak dinginkan sama sekali justru Islam historis menentang apalagi menggantikan temuan kebenaran Islam normatif.

\section{Epistemologi Integratif-Interkonektif sebagai Solusi Pertentangan Islam Normatif dan Historis dalam Kinerja Pendidikan}

Kekuatan dan kelemahan tentunya telah menjadi bagian yang tak terhindarkan dari masing-masing pencarian kebenaran dari dua kategori Islam di atas, Islam normatif dan Islam historis. Berpijak kuat pada masing-masing epistemologi hanya akan melahirkan perilaku pengagungan kebenaran milik masing-masing yang sesungguhnya dibangun di atas tongkak-tonggak kelebihan yang dimiliki, sedangkan lobang-lobang kelemahan sebagai bagian yang tak terpisahkan dari epistemologi selalu ditutup rapat sedemikian rupa, sehingga ideologisasi dan dogmatisasi menjadi satu-satunya pilihan bagi masing-masing kategori Islam di atas.

Upaya besar dari masing-masing kelompok akan selalu terus menerus ditebar baik secara struktural maupun kultural, sehingga sangat rentan memicu lahirnya resistensi sosial dan vertikal, disadari atau tidak disadari, tidak saja di kalangan intelektual, tetapi juga di kalangan masyarakat primordial. Dan tidak jarang pula institusi-institusi sosial didirikan oleh masing-masing kelompok sebagai instrumen bagi pengembangan kebenaran guna meraup lahan-lahan potensial bahkan nonpotensial.

\footnotetext{
${ }^{10}$ Raghib Al-Isfahani, Al-Zari'ah ila Makarim al-Syari'ah, Abu Yazid al-'Ajamiy (ed.) (Kairo: Dar al-Wafa', 1987), 58

${ }^{11}$ Amril M., Etika Islam..., 9
} 
Amril M.: Islam Normatif dan Historis (Faktual): Ziarah Epistemologi Integratif-Interkonektif dalam Pendidikan

Pertanyaan berikutnya adalah di mana posisi pendidikan sebagai lembaga dan institusi sosial yang sampai saat ini diapresiasi sebagai lembaga yang paling sistematis, efektif dan produktif guna membangun ilmu pengetahuan dan kemanusiaan serta peradaban yang berkeadilan, bahkan masa depan kehidupan umat manusia dalam arus kehidupan global. ${ }^{12}$

Ini artinya pendidikan memberikan kontribusi yang teramat besar bagi perilaku kehidupan manusia termasuk keyakinan dan world view massanya. Dalam konteks peran fungsional pendidikan yang amat menjanjikan seperti ini lah, sisi lain pendidikan, sangat menggoda bagi penguasa dan para ideologis lainnya memanfaatkan pendidikan sebagai jalan lempang dan mulus bagi kepentingan misi dan bahkan kepentingan ideologis mereka. Sedemikian rupa peran pendidikan dan sekolah sebagai wadah perubahan dan pengembangan yang menempatkan sekolah sebagai sarana kebaikan dan kebajikan rekayasa individual dan sosial pengembangan kemanusiaan ke arah pembangunan kehidupan masyarakat yang lebih baik. ${ }^{13}$ Menjadi tergerus dan terbelenggu oleh kepentingan tangan-tangan ideologi yang sengaja disebarluaskan.

Perjalanan pendidikan dalam sejarahnya sebagaimana yang diindikasikan pada paparan di atas memang tak dapat dinafikan dan disangkal. Contoh konkrit misalnya banyak ditemukan betapa pendidikan diberlangsungkan dan lembaga pendidikan didirikan dijadikan perpanjangan tangan yang menggurinda sebagai bentuk massification masing-masing kelompok, guna upaya ideologisasi dan dogmatisasi keyakinan mereka tersebar dalam ranah-ranah sosial. Tidak terkecuali, kondisi seperti ini juga berlangsung dalam perjalanan relasi pendidikan dan politik dalam dalam Islam. $^{14}$

Pendidikan yang menindas demikian kata Paulo Freire sungguh berlangsung secara masif dalam kinerja pendidikan apalagi dalam pembelajaran dinilainya merupakan penyimpangan pendidikan yang telah berlangsung cukup lama terutama pada masyarakat yang termarjinalkan secara struktural maupun kultural. Oleh karenanya, "berkesadaran" atau disebutnya dengan conscientizaco sebagai tawaran

\footnotetext{
${ }^{12}$ Muhmidayeli, Teori-teori Pengembangan Sumber Daya Manusia dalam Pendidikan (Bandung: Refika Aditama, 2014), x

${ }^{13}$ Muhmidayeli, "Islamic's Contribution in Education to Empower Human Resources," Makalah, Disampaikan dalam seminar Nasional di UNJ Jakarta, 2010, 93

${ }^{14}$ Amril M.,"Perjalanan Panjang Idiologisasi Pendidikan Islam yang Tercabik-Cabik," Makalah, Disampaikan pada kuliah umum di STAIS Air Molek, 2002, 4
} 
untuk membebaskan kinerja pendidikan dan pembelajaran dari penindasan dijadikan inti pendidikan bagi Freire. ${ }^{15}$

Mengingat conscientizaco ini bukanlah semisal teknik atau transfer informasi, atau bahkan untuk pelatihan keterampilan tetapi sesungguhnya merupakan proses dialogis yang menghantarkan individu secara bersama-sama untuk memecahkan masalah-masalah eksistensial mereka. ${ }^{16}$ Karenanya dialog interdependensi antara aksi sebagai realitas sosial dengan refleksi sebagai realitas intelektual merupakan alat pemutus perilaku penindasan termasuk dalam pendidikan dan pembelajaran.

Meminjam alur berpikir epistemologi Paul Freire, jika dizinkan, dalam membebaskan pendidikan dari perilaku penindasan dari kelompok mana saja maka dialogis tanpa dominasi antara Islam normatif dan Islam historis terus dihidupsuburkan meskipun perlu dicatat bahwa Islam historis tidak menggantikan Islam normatif begitu sebaliknya.

Memang alur epistemologi Paul Freire yang sama sekali tidak menginginkan memutus batas posisi dua entitas dalam pendidikan, misalnya antara guru dan siswa menurutnya bagaikan satu tubuh yang tak terpisahkan tentu sepenuhnya pemikiran beliau tidak dapat diadopsi secara utuh, karena bagaimanapun juga karakteristik epistemologi Islam normatif dan Islam historis memiliki cara kerja yang berbeda, namun mendialogkan antara keduanya merupakan sesuatu yang niscaya demi pemahaman yang komprehensif yang kualitas capaian kebenarannya, baik dalam perspektif metodis maupun logis, jauh lebih valid ketimbang pencarian tanpa adanya mitra dialog yang terbebas dari arogansi dan prasangka.

Selain itu, sesungguhnya dialogis berpikir epistemologi antara Islam normatif dan Islam historis selain tuntutan metodis yang menjanjikan untuk sebuah kebenaran yang komprehensif, juga di dalamnya ada tuntutan lain yakni tuntutan Islam sebagai agama rahmatan lil al-'alamin; Islam yang mengayomi, penyejuk dan elegan yang didorong oleh misi baikan dan kebajikan bagi seisi alam jagad raya tanpa diskriminatif dan represif.

Gambaran singkat Islam rahmatan lil al-'alamin seperti diungkap di atas sesungguhnya sangat dibutuhkan pada kehidupan era globalisasi saat ini melalui kinerja

\footnotetext{
${ }^{15}$ Made Pramono, "Menyelami Sprit Epistemologi Paul Freire," dalam Sulistiyono Santoso at all, Epistemologi Kiri (Yogyakarta: Ar-Ruzz Press, 2003), 33

${ }^{16}$ Ibid., 132
} 
Amril M.: Islam Normatif dan Historis (Faktual): Ziarah Epistemologi Integratif-Interkonektif dalam Pendidikan

pendidikan. Hal ini dikarenakan bahwa di antara misi substantif pendidikan itu ditujukan untuk melahirkan kebaikan dan kebajikan dalam kehidupan umat dan alam jagad raya melalui penumbuhkembangan sisi fisik-materialistik, psikis-humanistis dan etis-spritualistis. Sedemikian rupa pendidikan benar-benar meniscayakan ketenteraman, kedamaian elegan yang transformatif dan emansipatoris bagi kehidupan seluruh alam jagad raya. $^{17}$

Islam sebagai agama rahmatan lil al-'alamin yang berdimensi sosio-ekologi religius tentunya menuntut kinerja pendidikan untuk mengembangbiakkan dimensidimensi Islam rahmatan lil 'alamin ini tanpa henti, apalagi dalam arus era globalisasi saat ini yang penuh tantangan dan gocangan yang dengan sadar atau tidak, dapat saja dengan mudahnya menggeser bahkan menafikan kebenaran-kebenaran yang dianggap final selama ini.

Kritik tajam terhadap sebuah kebenaran dalam berbagai bidang kehidupan di era globalisasi merupakan sesuatu yang syah-syah saja terjadi, bahkan pembongkaran total terhadap sesuatu yang diyakini benar, apalagi sebuah kebenaran itu didapat melalui metoda yang telah disakralkan, imun dari metoda lain yang boleh jadi dapat memberikan kontribusi untuk menemukan sebuah kebenaran, saat ini telah menjadi sebuah keniscayaan.

Kesemua keniscayaan seperti dipaparkan di atas sesunguhnya tidak dapat dipisahkan dari watak dasar era globalisasi yang memang memicu lahirnya perubahan tanpa batas ruang dan waktu yang menjurus bersifat revolusioner sebagai akibat kemajuan ICT. $^{18}$

Pendapat lain juga mengatakan bahwa globalisasi saat ini telah menusuk pemikiran sejumlah besar anggota masyarakat sehingga globalisasi menjadi fenomena sosial yang memuat perubahan baik pada keragaman ataupun ketidapastian karena tingginya eskalasi dan dinamika cara berpikir dan bersikap masyarakat dalam

\footnotetext{
${ }^{17}$ Amril M., "The Existence of PTKIN in Globalization Era (a Review of Law No. 12 of 2012 and KKNI Curriculum in Frame Paradigm Integration of Religion and Science)," Makalah, Dipresentasikan pada AICIS 16, Serpong Tanggerang, 2017, 9

${ }^{18}$ Ishomuddin, "Some Islamic Higher Education Strategies to Tackle and Take Opportunities in the Era of Globalization,” Journal of Educationand Practies, Vol. 10. No. 6, 2014: 140
} 
menghadapi realitas. ${ }^{19}$ Sehingga globalisasi bukan hanya sebagai gejala dan proses baru, juga sebagai ideologi.

Kemunculan realitas sosial keberagamaan saat ini semisal Islam normatif dan Islam historis, sesungguhnya tidak dapat dipisahkan dari pengaruh dunia globalisasi, yang secara sadar atau tidak, telah menyeruak dalam sikap, berfikir dan bahkan mengekspresikan kebenaran keagamaan dalam kehidupan individual maupun sosial. Bahkan ekspresi kebebasan dalam keberagamaan yang plural seperti saat ini satu sisi dapat memicu lahirnya resistensi sosial, sisi lain melahirkan dorongan yang kuat pencarian kebenaran dari dinamika keragaman keberagamaan dalam kehidupan sosial. Seyogyanya pada bagian terakhir inilah kaum ilmuwan dan cendikiawan Muslim berkiprah, sehingga jalan panjang menuju Islam sebagai agama rahmatan lil al-'alamin setahap demi setahap tertelusuri, setidaknya melalui pemanfaatan kajian epistemologi.

Menghendaki kiprah luas Islam sebagai agama rahmatan lil 'alamin di tengah pesatnya perkembangan sains dan teknologi yang sangat akseleratif dan dinamika sosial yang sangat dinamis akan membawa pengaruh pada kualitas kebenaran sebagai hasil pencarian epistemologi, tentunya akan menjadi lebih memadai ketika memanfaatkan alat pencarian multidisipliner dibandingkan dengan monodisipliner dalam kondisi saat ini. $^{20}$

Upaya mendialogkan Islam normatif dan Islam historis dalam kajian epistemologi integratif-interkonektif setidaknya dapat dipinjam model Jaringan LabaLaba Keilmuan Teoantroposentrik-Integralistik yang digagas oleh M. Amin Abdullah, ${ }^{21}$ kemudian beliau kembangkan pula untuk kajian integrasi model ini apa yang disebutnya dengan Hadharat al-Nash (Budaya Teks), Hadharat al-'Ilm (Budaya Ilmu Pengetahuan) dan Hadharat al-Falasafah (Budaya Filosofis). Fungsi ketiga konsep ini ditujukan baginya untuk membuka ruang dialog dan mencairkan kebekuan hubungan antar berbagai disiplin keilmuan yang selama ini sulit teratasi, meskipun blok dan sekat antar disiplin keilmuan itu pada bagian tertentu tetap begitu adanya. ${ }^{22}$

\footnotetext{
${ }^{19}$ Muhammad M. Said, “The Continunity and Change of Indonesia's Islamic Higher Educational Institutions in The amid of Educational Police Change," Asian Social Science, Vol. 10, No. 6, 2014, 71

${ }^{20}$ M. Amin Abdullah, "Perkembangan Paradigma dan Pendekatan dalam Studi Islam di Indonesia," Makalah, Dipresentasikan pada AICIS ke-11, Bangka Belitung, 2011, 6

${ }^{21}$ M. Amin Abdullah, Islamic Studies..., 107

${ }^{22}$ Ibid., ix
} 
Amril M.: Islam Normatif dan Historis (Faktual): Ziarah Epistemologi Integratif-Interkonektif dalam Pendidikan

Hadharat al-Nash (Budaya Teks dan Turats) yang ditandai dengan upaya yang kuat untuk menggali, memahami dan menimbang kandungan isi teks keagamaan (alQur'an, Hadits dan teks Islam klasik) yang telah memiliki legalitas pada pendapat, teori, atau fatwa yang berakar pada teks-teks al-Qur'an dan Hadits atau pendapat ulama atau sarjana Muslim yang memiliki otoritas untuk kompetensi al-Qur'an dan Hadis dan turunannya. Karakter kebenaran yang niscaya didapat di antaranya cenderung berkarakter intelektualistik-teologik yang koherensif, namun mengabaikan intelektualistik-sosiologik bahkan antropologik dan saintifik sehingga kebenaran ilmu yang dihasilkan oleh piranti ini cenderung berada pada wilayah "semestinya" yang bersifat normatif.

Hadharat al-'Ilm (Budaya Ilmu Pengetahuan) yang ditandai dengan upaya yang kuat untuk menggali bidang-bidang keilmuan yang digeluti secara profesional, objektif dan inovatif. Sedemikian rupa aksentuasi orientasi kinerjanya cenderung pada sosialhumaniora, sains dan teknologi yang didukung fakta-fakta empiris baik dari fenomenafenomena sosial maupun fenomena alam. Karakter kebenaran yang niscaya lahir diantaranya cenderung berkarakter instrumentalis-teologis yang korespondensif.

Terakhir, Hadharat al-Falasafah (Budaya Filosofis-Etis) yang ditandai dengan upaya kuat untuk menimbang dan mengaitkan muatan kebenaran dengan tanggung jawab moral-etis, transformatif-emansipatoris. Aksentuasi orientasi kerjanya cenderung pada aspek tanggung jawab moral etis dalam praksis kehidupan riil di tengah-tengah masyarakat. Karenanya timbangan aksiologis-etis menjadi prioritas pada piranti ini. Tanggung jawab kebaikan dan kebajikan individual-sosial spritual dan transendental menjadi dasar sekaligus standar sebuah kebenaran. ${ }^{23}$

Bukan bermaksud meninggalkan model-model epistemologi integrasi yang ada saat ini, tapi pemanfaatan epistemologi integratif-interkonektif model "jaringan labalaba" milik M. Amin Abdullah ini dapat dikatakan memiliki kemanfaatan guna menjawab kebutuhan saat ini, terutama dari sisi metodologis implementasi dalam kinerja pendidikan dan penelitian misalnya.

Model integrasi-interkoneksi "jaringan laba-laba" ini secara eksplisit telah menampilkan secara tegas masing-masing wilayah kinerja integrasi-interkoneksi dalam

${ }^{23}$ Amril M, Epistemologi Integratif-Interkonektif Agama dan Sains (Menggali Potensi-Konsepsi Menuju Teori-Aplikasi dalam Pengembangan Ilmu Keislaman dan Pembelajaran), Rajawali Press, Jakarta, 2016 
pencarian kebenaran khususnya. Dalam model epistemologi ini al-Qur'an dan Sunnah yang dimaknai secara baru (hermeneutis) selalu dijadikan pijak pandangan hidup keagamaan manusia dan yang menyatu dalam satu tarikan nafas kehidupan keagamaan dan ilmu pengetahuan, kemudian metodologi dan pendekatan ilmu pada lingkar kedua yang mendasari berbagai ilmu seperti 'ulum al-din pada lingkar ketiga, selanjutnya pada lingkar keempat, natural science dan social science dan lingkaran selanjutnya humanities kontemporer. Kesemua ilmu-ilmu dalam lingkaran jaringan laba-laba ini secara vertikal maupun horizontal saling bersentuhan baik langsung maupun tidak langsung. ${ }^{24}$

Dalam pengertian ini dapat dikatakan pula, secara sederhana, bahwa metodologi dan pendekatan-pendekatan yang akan diterapkan yang ditempatkan pada lingkaran kedua di epistemologi integratif-interkonektif seperti ini, sesungguhnya merupakan gerak awal kinerja epistemologi model seperti ini. Dari sini dimulai 'ulum al-din bersentuhan dengan natural science (ilmu-ilmu alam) dan social science (ilmu-ilmu sosial) pada lingkar keempat, kemudian bersentuhan pula dengan humanities science (ilmu-ilmu humaniora) kontemporer. Kesemua disiplin ilmu-ilmu dalam lingkaran "jaringan laba-laba" ini dipersentuhkan dan diadialogkan baik dalam bingkai dialog horizontal, langsung atau dialog antara berbagai disiplin ilmu yang ada, atau dalam bentuk dialog vertikal baik langsung atau dialog antara yang terdapat dalam lingkaranlingkaran "jaringan laba-laba" pada epistemologi integratif-interkonektif ini. Kinerja epistemologi seperti ini tentu akan meniscayakan lahirnya kebenaran yang lebih komprehensif dibanding kebenaran yang hanya memanfaatkan satu epistemologi semata baik pada Islam normatif maupun Islam historis. Pada model "jaringan laba-laba" ini, al-Qur'an dan Sunnah yang telah dimaknai secara baru (hermeneutis) tetap dijadikan pijakan pandangan hidup guna mencari kebenaran dalam epistemologi integratifinterkonektif.

Epistemologi integratif-interkonektif model "jaringan laba-laba" ini akan semakin efektif dan fungsional baik dalam pendidikan dan pembelajaran serta penelitian ketika diikutkan apa yang disebut dengan Hadharat an-Nash (Budaya Teks dan Turats), Hadharat al-'Ilm (Budaya Ilmu Pengetahuan) dan Hadharat al-Falasafah (Budaya Filosofis-Etis).

\footnotetext{
${ }^{24}$ M. Amin Abdullah, Islamic Studies...
} 
Melalui epistemologi integratif-interkonektif model "jaringan laba-laba" ini akan meniscayakan kebenaran yang lebih komprehensif, fungsional dalam menjawab tantangan kekinian termasuk problema Islam normatif dan Islam historis dalam mencari kebenaran. Hal ini secara metodis pencarian kebenaran mengikutsertakan berbagai perspektif disiplin keilmuan dengan tetap menempatkan al-Qur'an dan Sunnah sebagai pijakan pandangan dunia pencarian kebenaran.

Menerapkan epistemologi integratif-interkonektif pada kajian ilmu keIslaman ini meniscayakan segala hiruk pikuk perilaku keberagamaan dalam beberapa istilah yang marak saat ini seperti Islam normatif, Islam historis bahkan Islam liberal setidaknya niscaya akan dapat meraih kebenaran yang jauh lebih utuh yang tidak tersekat kaku oleh dinding ideologis dan antagonistis yang hanya dihasilkan oleh epistemologi yang anti integratif-interkonektif.

Penerapan epistemologi integratif-interkonektif model ini baik dalam pendidikan khususnya lagi di lembaga-lembaga pendidikan Islam sampai PTKIN/S sudah mendesak diterapkan, selain dapat menjawab tuntutan dan kebutuahan dinamika sosial keberagamaan, berpikir tentang keagamaan dan bersikap dan berperilaku dalam kehidupan sosial keberagamaan, juga pemahaman keagamaan dan keberagamaan guna mencari kebenaran yang komprehensif sebagai salah satu basis terwujudnya Islam rahmatan lil al-'alamin.

Kecuali itu tentunya epistemologi integratif-interkonektif model "jaringan labalaba" ini merupakan jawaban keniscayaan terbukanya dialog antara Islam normatif dan Islam historis seperti pertanyaan awal dalam tulisan ini sehingga truth claim (klaim kebenaran) masing-masing dapat dipahami secara proporsional. Begitu pula integrasiinterkoneksi model ini dapat mengurangi keragaman ketegangan keberagamaan yang terjelma dalam kehidupan sosial secara rasional dan profesional yang terbebas dari letupan-letupan emosi dan represi.

\section{Kesimpulan}

Hiruk-pikuk klaim kebenaran sepihak oleh masing-masing kelompok dalam perilaku keberagamaan yang nyaris menyulut resistensi dan konflik sosial di tengah masyarakat sesungguhnya tidak dapat dipisahkan dari aktivitas pencarian kebenaran sebagai hulu lahirnya klaim kebenaran keberagamaan. Karenanya kajian ilmu 
Amril M.: Islam Normatif dan Historis (Faktual): Ziarah Epistemologi Integratif-Interkonektif dalam Pendidikan

keagamaan yang berwatak epistemologi integratif-interkonektif seperti ini dapat dikatakan jawaban untuk mengurai dan mencairkan simpul-simpul dogmatisasi dan ideologi yang telah terlanjur membenih subur di tengah masyarakat.

Mengaplikasikan epistemologi integratif-interkonektif dengan menjalinkelindankan tiga pirantinya: Hadharat an-Nash (Budaya Teks dan Turats), Hadharat al'Ilm (Budaya Ilmu Pengetahuan) dan Hadharat al-Falasafah (Budaya Filosofis-Etis) ini selain diyakini mampu menetralisir atau paling tidak mencairkan kebekuan antara Islam normatif dan Islam historis, juga capaian kebenaran yang akan dihasilkannya tentu jauh lebih mendekati kebenaran yang lebih komprehensif dibandingkan bila dilakukan hanya dengan satu kategori epistemologi saja.

Pendidikan Islam baik sebagai kelembagaan maupun mata pelajaran atau mata kuliah termasuk penelitian-penelitian dan pengembangan ilmu-ilmu keIslaman khususnya yang berparadigma epistemologis integratif-interkonektif menjadi instrumen yang strategis guna mengungkap pesan-pesan ideal moral dalam Islam, kemudian menggapainya sehingga damai-mendamaikan nasehat-menasehati yang terlepas dari dominasi dan represif sebagai bentuk nyata watak Islam rahmatan lil al'alamin dalam realitas sosial kehidupan semakin fungsional.

\section{E. Daftar Pustaka}

Susanto, Heri. "Metode Dekonstruksi Jacques Derrida: Kritik atas Metapisika dan Epistemologi Moder.” Santoso, Listiyono, et.al., Epistemologi Kiri. Yogyakarta: Ar-Ruzz, 2009

M, Amril. Epistemologi Integratif-Interkonektif Agama dan Sains (Menggali PotensiKonsepsi Menuju Teori-Aplikasi dalam Pengembangan Ilmu Keislaman dan Pembelajaran). Jakarta: Rajawali Press, 2016

Wall, Thomas F. Thinking Critically About Philosophical Problems. London: Wadworth, 2001.

Smart, Ninian. "Pengantar Aneka Pendekatan Studi Agama." Connolly, Peter. Aneka Pendekatan Studi Agama. Terj. Imam Khoiri. Yogyakarta: LkiS, 2002.

Rahman, Fazlur. Islam. Terj. Ahsin Muhammad. Bandung: Pustaka, 1984

Abdullah, M. Amin. Islamic Studies di Perguruan Tinggi Pendekatan IntegratifInterkonektif. Yogyakarta: Pustaka Pelajar, 2006.

M, Amril. Etika Islam: Telaah Pemikiran Filsafat Moral Raghib al-Isfahani. Yogyakarta: Pustaka Pelajar, 2002.

Bagus, Leorens. Kamus Filsafat. Jakarta: Gramedia, 1996. 
Al-Isfahani, Raghib. Al-Zari'ah ila Makarim al-Syari'ah. Al-'Ajamiy, Abu Yazid (ed.) Kairo: Dar al-Wafa', 1987.

Muhmidayeli. Teori-teori Pengembangan Sumber Daya Manusia dalam Pendidikan. Bandung: Refika Aditama, 2014.

Muhmidayeli. "Islamic's Contribution in Education to Empower Human Resources." Makalah. Disampaikan dalam seminar Nasional di UNJ Jakarta, 2010.

M, Amril. "Perjalanan Panjang Idiologisasi Pendidikan Islam yang Tercabik-Cabik." Makalah. Disampaikan pada kuliah umum di STAIS Air Molek, 2002.

Pramono, Made. "Menyelami Sprit Epistemologi Paul Freire." Dalam Sulistiyono Santoso, et.al. Epistemologi Kiri. Yogyakarta: Ar-Ruzz Press, 2003.

M, Amril. "The Existence of PTKIN in Globalization Era (a Review of Law No. 12 of 2012 and KKNI Curriculum in Frame Paradigm Integration of Religion and Science)." Makalah. Dipresentasikan pada AICIS 16, Serpong Tanggerang, 2017.

Ishomuddin "Some Islamic Higher Education Strategies to Tackle and Take Opportunities in the Era of Globalization." Journal of Educationand Practies, Vol. 10. No. 6, 2014: 140

M. Said, Muhammad. "The Continunity and Change of Indonesia's Islamic Higher Educational Institutions in The amid of Educational Police Change." Asian Social Science, Vol. 10, No. 6, 2014, 71

Abdullah, M. Amin. "Perkembangan Paradigma dan Pendekatan dalam Studi Islam di Indonesia." Makalah. Dipresentasikan pada AICIS ke-11, Bangka Belitung, 2011 .

M, Amril. Epistemologi Integratif-Interkonektif Agama dan Sains (Menggali PotensiKonsepsi Menuju Teori-Aplikasi dalam Pengembangan Ilmu Keislaman dan Pembelajaran). Rajawali Press, Jakarta, 2016. 